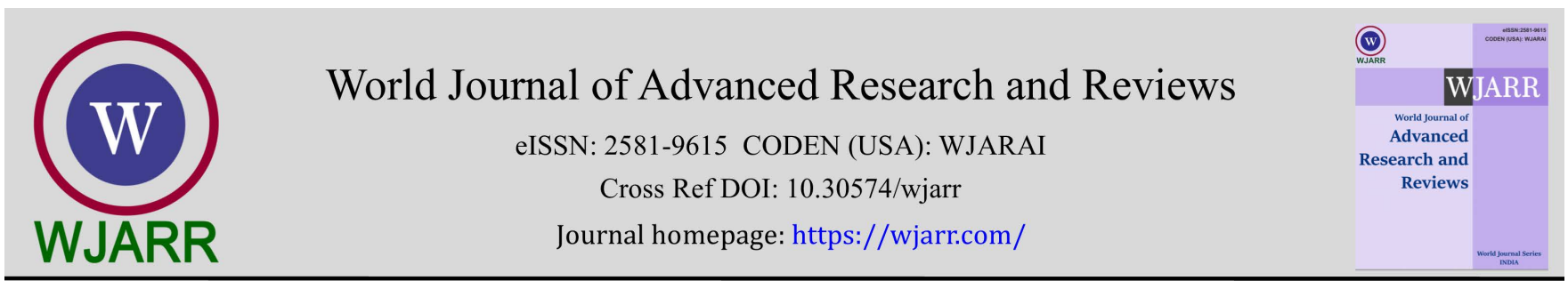

(RESEARCH ARTiClE)

\title{
Comparison of Chemical Element Contents in Thyroid Goiter, Adenoma, and Thyroiditis investigated using Neutron Activation Analysis
}

\author{
Vladimir Zaichick ${ }^{*}$ \\ Radionuclide Diagnostics Department Medical Radiological Research Centre Obninsk, Russia.
}

World Journal of Advanced Research and Reviews, 2021, 12(03), 098-107

Publication history: Received on 25 October 2021; revised on 30 November 2021; accepted on 02 December 2021

Article DOI: https://doi.org/10.30574/wjarr.2021.12.3.0656

\begin{abstract}
Thyroid benign nodules (TBNs) are the most common lesions of this endocrine gland. Among TBNs the colloid goiter (CG), thyroiditis (T), and thyroid adenoma (TA) are the most frequent diseases. An evaluation of the variant of TBNs is clinically important for subsequent therapeutic interventions, as well as for more clear understanding the etiology of these disorders. The aim of this exploratory study was to examine differences in the content of bromine (Br), calcium (Ca), chlorine $(\mathrm{Cl})$, iodine $(\mathrm{I})$, potassium $(\mathrm{K})$, magnesium $(\mathrm{Mg})$, manganese $(\mathrm{Mn})$, and sodium (Na) in tissues of CG, TA, and T. Thyroid tissue levels of eight chemical elements (ChE) were prospectively evaluated in 46 patients with CG, 19 patients with TA, and 12 patients with T. Measurements were performed using non-destructive instrumental neutron activation analysis with high resolution spectrometry of short-lived radionuclides. Tissue samples were divided into two portions. One was used for morphological study while the other was intended for ChE analysis. It was observed that in CG, TA and T tissues content of Br was significantly higher, while level of I was lower than in normal thyroid tissue. I accumulation in T tissue was lower than in normal thyroid and CG. Abnormal increase in Br level and decrease in I level in all TBNs might demonstrate an involvement of these ChE in etiology and pathogenesis of TBNs. It was suosed that great losses of I in thyroid with T, in contract to little reduced levels of I content in thyroid with CG and TA, could possibly be explored for differencial diagnosis of $\mathrm{T}$.
\end{abstract}

Keywords: Thyroid; Thyroid colloid goiter; Thyroid adenoma; Thyroiditis; Chemical elements; Neutron activation analysis

\section{Introduction}

Thyroid benign nodules (TBNs) are the most common lesions of this endocrine gland that encountered globally and frequently discovered by palpation during a physical examination, or incidentally, during clinical imaging procedures. TBNs include non-neoplastic lesions (different kinds of thyroid goiter, thyroiditis, and cysts) and neoplastic lesion such as thyroid adenoma. Among TBNs the colloid goiter (CG), thyroiditis (T), and thyroid adenoma (TA) are the most frequent diseases [1-3]. An evaluation of the variant of TBNs is clinically important for subsequent therapeutic interventions. For this reason the finding of specific characteristics of various TBNs is the barest necessity for the differential diagnosis of these thyroid disorders.

For over 20th century, there was the dominant opinion that TBNs is the simple consequence of iodine deficiency. However, it was found that TBNs is a frequent disease even in those countries and regions where the population is never exposed to iodine shortage [4]. Moreover, it was shown that iodine excess has severe consequences on human health and associated with the presence of TBNs [5-8]. It was also demonstrated that besides the iodine deficiency and excess many other dietary, environmental, and occupational factors are associated with the TBNs incidence [9-11]. Among

\footnotetext{
${ }^{*}$ Corresponding author: Vladimir Zaichick

Radionuclide Diagnostics Department Medical Radiological Research Centre Obninsk, Russia. 
these factors a disturbance of evolutionary stable input of many chemical elements (ChE) in human body after industrial revolution plays a significant role in etiology of TBNs [12].

Besides iodine, many other ChE have also essential physiological functions [13]. Essential or toxic (goitrogenic, mutagenic, carcinogenic) properties of ChE depend on tissue-specific need or tolerance, respectively [13]. Excessive accumulation or an imbalance of the ChE may disturb the cell functions and may result in cellular degeneration, death, benign or malignant transformation [13-15].

In our previous studies the complex of in vivo and in vitro nuclear analytical and related methods was developed and used for the investigation of iodine and other ChE contents in the normal and pathological thyroid [16-22]. Iodine level in the normal thyroid was investigated in relation to age, gender and some non-thyroidal diseases [23, 24]. After that, variations of many ChE content with age in the thyroid of males and females were studied and age- and genderdependence of some ChE was observed [25-41]. Furthermore, a significant difference between some ChE contents in CG, TA, and T in comparison with normal thyroid was demonstrated [42-46].

To date, the etiology and pathogenesis of TBNs has to be considered as multifactorial. The present study was performed to find differences in ChE contents between CG, TA, and T grouof samples, as well as to clarify the role of some ChE in the TBNs etiology. Having this in mind, our aim was to assess the bromine (Br), calcium (Ca), chlorine (Cl), iodine (I), potassium (K), magnesium (Mg), manganese (Mn), and sodium (Na) contents in CG, TA, and T tissue samples using nondestructive instrumental neutron activation analysis with high resolution spectrometry of short-lived radionuclides. (INAA-SLR). A further aim was to compare the levels of these ChE in CG, TA, and T grouof samples between each other.

\section{Material and methods}

All patients suffered from CG ( $n=46$, mean age $M \pm S D$ was 48 \pm 12 years, range $30-64)$, TA ( $n=19$, mean age $M \pm S D$ was $41 \pm 11$ years, range $22-55$ ), and $T$ (mean age $M \pm S D$ was $39 \pm 9$ years, range $34-50$ ) were hospitalized in the Head and Neck Department of the Medical Radiological Research Centre. The grouof patients with T included 8 persons with Hashimoto's thyroiditis and 6 persons with Riedel's Struma. Thick-needle puncture biopsy of suspicious nodules of the thyroid was performed for every patient, to permit morphological study of thyroid tissue at these sites and to estimate their TE contents. For all patients the diagnosis has been confirmed by clinical and morphological/histological results obtained during studies of biopsy and resected materials.

All tissue samples were divided into two portions using a titanium scalpel [47]. One was used for morphological study while the other was intended for TE analysis. After the samples intended for TE analysis were weighed, they were freeze-dried and homogenized [48]. The pounded samples weighing about $10 \mathrm{mg}$ (for biopsy) and $100 \mathrm{mg}$ (for resected materials) were used for ChE measurement by INAA-SLR.

To determine contents of the ChE by comparison with a known standard, biological synthetic standards (BSS) prepared from phenol-formaldehyde resins were used [49]. In addition to BSS, aliquots of commercial, chemically pure compounds were also used as standards. Ten sub-samples of certified reference material (CRM) of the International Atomic Energy Agency (IAEA) IAEA H-4 (animal muscle) weighing about $100 \mathrm{mg}$ were treated and analyzed in the same conditions as thyroid samples to estimate the precision and accuracy of results.

The content of $\mathrm{Br}, \mathrm{Ca}, \mathrm{Cl}, \mathrm{I}, \mathrm{K}, \mathrm{Mg}, \mathrm{Mn}$, and Na were determined by INAA-SLR using a horizontal channel equied with the pneumatic rabbit system of the WWR-c research nuclear reactor (Branch of Karpov Institute, Obninsk). Details of used nuclear reactions, radionuclides, gamma-energies, spectrometric unit, sample preparation, and the quality control of results were presented in our earlier publications concerning the INAA-SLR of ChE contents in human thyroid, scalhair, and prostate $[27,28,50-52]$.

A dedicated computer program for INAA-SLR mode optimization was used [53]. All thyroid samples were prepared in duplicate, and mean values of ChE contents were used in final calculation. Using Microsoft Office Excel software, a summary of the statistics, including, arithmetic mean, and standard deviation, standard error of mean, minimum and maximum values, median, percentiles with 0.025 and 0.975 levels was calculated for ChE contents in CG, TA, and T tissue samples. The difference in the results between three groups of samples (CG, TA, and T) was evaluated by the parametric Student's $t$-test and non-parametric Wilcoxon-Mann-Whitney $U$-test. 


\section{Results}

Table 1 presents certain statistical parameters (arithmetic mean, standard deviation, standard error of mean, minimal and maximal values, median, percentiles with 0.025 and 0.975 levels) of the $\mathrm{Br}, \mathrm{Ca}, \mathrm{Cl}, \mathrm{I}, \mathrm{K}, \mathrm{Mg}$, $\mathrm{Mn}$, and $\mathrm{Na}$ mass fraction in CG, TA, and T tissue samples.

The ratios of means and the comparison of mean values of $\mathrm{Br}, \mathrm{Ca}, \mathrm{Cl}, \mathrm{I}, \mathrm{K}, \mathrm{Mg}, \mathrm{Mn}$, and $\mathrm{Na}$ mass fractions in pairs of sample groups such as CG and TA, CG and T, and TA and T are presented in Table 2, 3, and 4, respectively.

Table 5 depicts the results of comparison the contents of $\mathrm{Br}, \mathrm{Ca}, \mathrm{Cl}, \mathrm{I}, \mathrm{K}, \mathrm{Mg}, \mathrm{Mn}$, and $\mathrm{Na}$ in $\mathrm{CG}$, TA, and T sample groups with those in normal thyroid [43-46], as well as comparison the contents of these ChE in CG, TA, and T sample groups among themselves.

\section{Discussion}

As was shown before [27,28,50-52] good agreement of the $\mathrm{Br}, \mathrm{Ca}, \mathrm{Cl}, \mathrm{I}, \mathrm{K}, \mathrm{Mg}, \mathrm{Mn}$, and $\mathrm{Na}$ contents in CRM IAEA H-4 samples analyzed by INAA-SLR with the certified data of this CRM indicates acceptable accuracy of the results obtained in the study of CG, TA, and T samples presented in Tables 1-5.

In a general sense variations found for $\mathrm{Br}, \mathrm{Ca}, \mathrm{Cl}, \mathrm{I}, \mathrm{K}, \mathrm{Mg}, \mathrm{Mn}$, and $\mathrm{Na}$ contents during the goitrous and adenomatous transformations of thyroid were very similar (Table 2 and 5). The $\mathrm{Br}, \mathrm{Cl}$, and $\mathrm{Na}$ contents in goitrous and adenomatous thyroid were higher, while I content was lower in comparison with contents of these ChE in normal gland (Table 5). There was not found any differences between ChE contents of CG and TA, with the exception of Br and Mg (Table 2 and 5). The Br level in TA tissue was almost 8 times higher, while the Mg content was 1.8 times lower than in CG tissue.

The variations found for $\mathrm{Br}, \mathrm{Ca}, \mathrm{Cl}, \mathrm{I}, \mathrm{K}, \mathrm{Mg}, \mathrm{Mn}$, and $\mathrm{Na}$ in thyroid with $\mathrm{T}$ were some differ than the variations of these ChE in CG and TA tissues. Variations of $\mathrm{Br}$ and I contents in $\mathrm{T}$ samples were similar those in CG and TA tissues, but among other ChE investigated in T samples only Ca content was lower in comparison with normal thyroid (Table 5). The content of Br was higher, whereas the Ca and I levels were lower in T samples than levels of these ChE in CG samples (Table 3 and 5). Only the Mg content was higher, when results for ChE in T samples were compared with those in TA samples (Table 4 and 5).

In this study, content of $\mathrm{Cl}, \mathrm{K}, \mathrm{Mn}$, and $\mathrm{Na}$ in goitrous thyroid were compared with those from adenomatous thyroids and from thyroid with $\mathrm{T}$.

Published data on comparison of $\mathrm{Br}, \mathrm{Ca}, \mathrm{Cl}, \mathrm{I}, \mathrm{K}, \mathrm{Mg}, \mathrm{Mn}$, and $\mathrm{Na}$ levels in the different thyroid lesions such as CG, TA and T were not found.

Thus, from obtained results it was possible to conclude that the common characteristics of CG, TA and T samples were elevated level of $\mathrm{Br}$ and reduced level of I in comparison with normal thyroid and, therefore, these ChE are involved in etiology or pathogenesis of such thyroid disorders as CG, TA and T.

$\mathrm{Br}$ is one of the most abundant and ubiquitous of the recognized $\mathrm{ChE}$ in the biosphere. Inorganic bromide is the ionic form of bromine which exerts therapeutic as well as toxic effects. An enhanced intake of bromide could interfere with the metabolism of iodine at the whole-body level. In the thyroid gland the biological behavior of bromide is more similar to the biological behavior of iodide [54]. A significant age-related increase of $\mathrm{Br}$ content in human thyroid [25-28] correlated well with age-related prevalence of CG, TA and T [55-57]. The main source of natural Br for human body is food. Environment (air, water and food) polluted by artificial Br-contained compounds, for example such as polybrominated biphenyls (PBBs) and diphenyl ethers (PBDEs), is other source. PBBs and PBDEs impact on thyroid function and thyroid hormones metabolism [58] Thus, on the one hand, the accumulated data suggest that Br level in thyroid tissue might be responsible for CG, TA, and T development. But, on the other hand, Br compounds, especially potassium bromide $(\mathrm{KBr})$, sodium bromide $(\mathrm{NaBr})$, and ammonium bromide $\left(\mathrm{NH}_{4} \mathrm{Br}\right)$, are frequently used as sedatives in Russia [59]. It may be the reason for elevated levels of $\mathrm{Br}$ in specimens of patients with CG, TA and T in comparison with normal thyroid. A nonuniform level of this TE in tissue of thyroid legions TA $\mathrm{Br}>\mathrm{T} \mathrm{Br}>\mathrm{CG}$ Br may be explained by the different strength of emotional reactions of persons on the diagnosis Ta, T, and CG, and, as consiquence, different dozes of Br-conteined sedatives, which were used. 
Compared to other soft tissues, the human thyroid gland has higher levels of I, because this element plays an important role in its normal functions, through the production of thyroid hormones (thyroxin and triiodothyronine) which are essential for cellular oxidation, growth, reproduction, and the activity of the central and autonomic nervous system. Goitrous and adenomatous transformation, as well as thyroiditis are probably accompanied by a partial loss of tissuespecific functional features, which leads to a modest (CG and TA) or severe (T) reduction in I content associated with functional characteristics of the human thyroid tissue. Great losses of I in thyroid with T, in contract to little reduced levels of I content in thyroid with CG and TA, could possibly be explored for differencial diagnosis of T.

Table 1 Some statistical parameters of $\mathrm{Br}, \mathrm{Ca}, \mathrm{Cl}, \mathrm{I}, \mathrm{K}, \mathrm{Mg}$, $\mathrm{Mn}$, and $\mathrm{Na}$ mass fraction (mg/kg, dry mass basis) in thyroid colloid goiter, adenoma and thyroiditis

\begin{tabular}{|c|c|c|c|c|c|c|c|c|c|}
\hline Tissue & Element & Mean & SD & SEM & Min & Max & Median & P 0.025 & P 0.975 \\
\hline Goiter & $\mathrm{Br}$ & 36.3 & 31.3 & 7.0 & 8.00 & 131 & 26.6 & 8.95 & 110 \\
\hline \multirow[t]{7}{*}{$n=46$} & $\mathrm{Ca}$ & 1393 & 855 & 168 & 209 & 4333 & 1280 & 258 & 3219 \\
\hline & $\mathrm{Cl}$ & 9117 & 3866 & 1223 & 4226 & 16786 & 8259 & 4504 & 15869 \\
\hline & I & 1141 & 931 & 145 & 29 & 3715 & 927 & 106 & 3617 \\
\hline & $\mathrm{K}$ & 6518 & 2304 & 443 & 3353 & 12222 & 6185 & 3395 & 10984 \\
\hline & $\mathrm{Mg}$ & 351 & 148 & 28 & 13 & 612 & 371 & 45.5 & 550 \\
\hline & $\mathrm{Mn}$ & 1.78 & 1.13 & 0.23 & 0.370 & 5.50 & 1.70 & 0.418 & 4.12 \\
\hline & $\mathrm{Na}$ & 11335 & 3597 & 705 & 7229 & 22381 & 10413 & 7277 & 19009 \\
\hline Аденома & $\mathrm{Br}$ & 286 & 330 & 104 & 3.2 & 871 & 133 & 5.09 & 841 \\
\hline \multirow[t]{7}{*}{$\mathrm{n}=19$} & $\mathrm{Ca}$ & 1143 & 1135 & 342 & 52 & 3582 & 650 & 110 & 3353 \\
\hline & $\mathrm{Cl}$ & 7722 & 3785 & 1262 & 1757 & 13824 & 9085 & 2043 & 13179 \\
\hline & I & 961 & 1013 & 232 & 131 & 3906 & 476 & 170 & 3591 \\
\hline & $\mathrm{K}$ & 5137 & 2474 & 686 & 797 & 8436 & 5741 & 937 & 8216 \\
\hline & $\mathrm{Mg}$ & 200 & 131 & 36 & 15.0 & 397 & 269 & 15.0 & 376 \\
\hline & $\mathrm{Mn}$ & 1.60 & 1.77 & 0.51 & 0.100 & 5.54 & 9.65 & 0.210 & 5.08 \\
\hline & $\mathrm{Na}$ & 9072 & 3952 & 1096 & 2319 & 16414 & 9100 & 2728 & 15822 \\
\hline Thyroiditis & $\mathrm{Br}$ & 85 & 35 & 13 & 38.0 & 125 & 78 & 40.6 & 125 \\
\hline \multirow[t]{7}{*}{$\mathrm{n}=14$} & $\mathrm{Ca}$ & 694 & 421 & 188 & 111 & 1169 & 775 & 145 & 1149 \\
\hline & $\mathrm{Cl}$ & 7160 & 3541 & 1771 & 3499 & 10487 & 7328 & 3594 & 10442 \\
\hline & I & 662 & 604 & 161 & 83.0 & 1787 & 356 & 83.7 & 1735 \\
\hline & $\mathrm{K}$ & 7268 & 1947 & 974 & 5690 & 10111 & 6635 & 5759 & 9852 \\
\hline & $\mathrm{Mg}$ & 514 & 232 & 95 & 306 & 844 & 419 & 309 & 835 \\
\hline & $\mathrm{Mn}$ & 2.33 & 1.72 & 0.70 & 0.570 & 5.26 & 2.09 & 0.615 & 4.98 \\
\hline & $\mathrm{Na}$ & 8271 & 3262 & 1332 & 3732 & 11861 & 9386 & 3862 & 11690 \\
\hline
\end{tabular}

$\mathrm{Cl}$ and $\mathrm{Na}$ are ubiquitous, extracellular electrolytes essential to more than one metabolic pathway. In the body, $\mathrm{Cl}$ and $\mathrm{Na}$ mostly present as sodium chloride. Therefore, as usual, there is a correlation between $\mathrm{Na}$ and $\mathrm{Cl}$ contents in tissues and fluids of human body. Because $\mathrm{Cl}$ is halogen like $\mathrm{I}$ and $\mathrm{Br}$, in the thyroid gland the biological behavior of chloride has to be similar to the biological behavior of iodide. The main source of natural $\mathrm{Cl}$ for human body is salt in food and chlorinated drinking water. Environment (air, water and food) polluted by artificial nonorganic Cl-contained compounds, for example such as sodium chlorate $\left(\mathrm{NaClO}_{3}\right)$, and organic $\mathrm{Cl}$-contained compounds, for example such as 
polychlorinated biphenyls (PCBs) and dioxin, is other source. There is a clear association between using chlorinated drinking water, levels $\mathrm{NaClO}_{3}$, PCBs and dioxin in environment and thyroid disorders, including cancer [58,60-63\}. Thus, on the one hand, the accumulated data suggest that $\mathrm{Cl}$ level in thyroid tissue might be responsible for CG and TA development. However, on the other hand, it is well known that $\mathrm{Cl}$ and $\mathrm{Na}$ mass fractions in human tissue samples depend mainly on the extracellular water volume [64]. Goitrous and adenomatous tissues can contain more colloid that normal thyroid. Because colloid is extracellular liquid, it is possible to speculate that CG and TA are characterized by an increase of the mean value of the $\mathrm{Cl}$ and $\mathrm{Na}$ mass fractions because the relative content of colloid in these thyroid lesions is higher than that in normal thyroid tissue. Overall, the elevated levels of $\mathrm{Cl}$ in goutrous and adenomatous thyroids could possibly be explored for diagnosis of CG and TA.

Table 2 Differences between mean values $(\mathrm{M} \pm \mathrm{SEM}$ ) of $\mathrm{Br}, \mathrm{Ca}, \mathrm{Cl}, \mathrm{I}, \mathrm{K}, \mathrm{Mg}, \mathrm{Mn}$, and $\mathrm{Na}$ mass fraction (mg/kg, dry mass basis) in thyroid colloid goiter and adenoma

\begin{tabular}{|l|c|c|c|c|c|}
\hline \multirow{2}{*}{ Element } & \multicolumn{3}{|c|}{ Thyroid tissue } & Ratio \\
\cline { 2 - 6 } & Goiter $\mathbf{n = 4 6}$ & Аденома $\mathbf{n = 1 9}$ & Student's t-test $\mathbf{p} \leq$ & U-test p & Goiter to Аденома \\
\hline $\mathrm{Br}$ & $36.3 \pm 7.0$ & $286 \pm 104$ & $\mathbf{0 . 0 4 0}$ & $\leq \mathbf{0 . 0 1}$ & 0.13 \\
\hline $\mathrm{Ca}$ & $1393 \pm 168$ & $1143 \pm 342$ & 0.521 & $>0.05$ & 1.22 \\
\hline $\mathrm{Cl}$ & $9117 \pm 1223$ & $7722 \pm 1262$ & 0.438 & $>0.05$ & 1.18 \\
\hline $\mathrm{I}$ & $1141 \pm 145$ & $961 \pm 232$ & 0.518 & $>0.05$ & 1.19 \\
\hline $\mathrm{K}$ & $6518 \pm 443$ & $5137 \pm 686$ & 0.105 & $>0.05$ & 1.27 \\
\hline $\mathrm{Mg}$ & $351 \pm 28$ & $200 \pm 36$ & $\mathbf{0 . 0 0 3 0}$ & $\leq \mathbf{0 . 0 1}$ & 1.76 \\
\hline $\mathrm{Mn}$ & $1.78 \pm 0.23$ & $1.60 \pm 0.51$ & 0.741 & $>0.05$ & 1.11 \\
\hline $\mathrm{Na}$ & $11335 \pm 705$ & $9072 \pm 1096$ & 0.096 & $>0.05$ & 1.25 \\
\hline
\end{tabular}

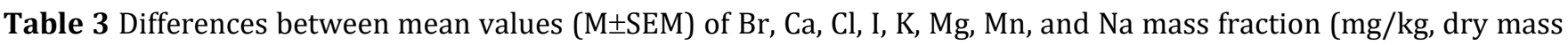
basis) in thyroid colloid goiter and thyroiditis

\begin{tabular}{|l|c|c|c|c|c|}
\hline \multirow{2}{*}{ Element } & \multicolumn{3}{|c|}{ Thyroid tissue } & Ratio \\
\cline { 2 - 6 } & Goiter $\mathbf{n = 4 6}$ & Thyroiditis $\mathbf{n = 1 4}$ & Student's t-test $\boldsymbol{p} \leq$ & U-test $\boldsymbol{p}$ & Goiter to Thyroiditis \\
\hline $\mathrm{Br}$ & $36.3 \pm 7.0$ & $85 \pm 13$ & $\mathbf{0 . 0 0 9 3}$ & $\leq \mathbf{0 . 0 1}$ & 0.43 \\
\hline $\mathrm{Ca}$ & $1393 \pm 168$ & $694 \pm 188$ & $\mathbf{0 . 0 1 7}$ & $\mathbf{5 0 . 0 1}$ & 2.01 \\
\hline $\mathrm{Cl}$ & $9117 \pm 1223$ & $7160 \pm 1771$ & 0.397 & $>0.05$ & 1.27 \\
\hline $\mathrm{I}$ & $1141 \pm 145$ & $662 \pm 161$ & $\mathbf{0 . 0 3 4}$ & $\leq \mathbf{0 . 0 1}$ & 1.72 \\
\hline $\mathrm{K}$ & $6518 \pm 443$ & $7268 \pm 974$ & 0.519 & $>0.05$ & 0.90 \\
\hline $\mathrm{Mg}$ & $351 \pm 28$ & $514 \pm 95$ & 0.153 & $>0.05$ & 0.68 \\
\hline $\mathrm{Mn}$ & $1.78 \pm 0.23$ & $2.33 \pm 0.70$ & 0.489 & $>0.05$ & 0.76 \\
\hline $\mathrm{Na}$ & $11335 \pm 705$ & $8271 \pm 1332$ & 0.076 & $>0.05$ & 1.37 \\
\hline
\end{tabular}

Characteristically, elevated or reduced levels of ChE observed in thyroid nodules are discussed in terms of their potential role in the initiation and promotion of these thyroid lesions. In other words, using the low or high levels of the ChE in affected thyroid tissues researchers try to determine the role of the deficiency or excess of each ChE in the etiology and pathogenesis of thyroid diseases. In our opinion, abnormal levels of many ChE in benign thyroid nodules could be and cause, and also effect of thyroid tissue transformation. From the results of such kind studies, it is not always possible to decide whether the measured decrease or increase in ChE level in pathologically altered tissue is the reason for alterations or vice versa. 
This study has several limitations. Firstly, analytical techniques employed in this study measure only eight $\mathrm{ChE}(\mathrm{Br}$, Ca, $\mathrm{Cl}, \mathrm{I}, \mathrm{K}, \mathrm{Mg}, \mathrm{Mn}$, and $\mathrm{Na}$ ) mass fractions. Future studies should be directed toward using other analytical methods which will extend the list of $\mathrm{ChE}$ investigated in normal thyroid and in pathologically altered tissue. Secondly, the sample size of CG grouand particularly of TA and T groups was relatively small and prevented investigations of ChE contents in these groups using differentials like gender, histological types of CG, TA and T, nodules functional activity, stage of disease, dietary habits of patients with CG, TA and T. Lastly, generalization of our results may be limited to Russian population. Despite these limitations, this study provides evidence on TBNs-specific tissue $\mathrm{Br}, \mathrm{Cl}, \mathrm{I}$, and $\mathrm{Na}$ level alteration and shows the necessity to continue ChE research of thyroid benign nodules.

Table 4 Differences between mean values ( $\mathrm{M} \pm \mathrm{SEM}$ ) of $\mathrm{Br}, \mathrm{Ca}, \mathrm{Cl}, \mathrm{I}, \mathrm{K}, \mathrm{Mg}, \mathrm{Mn}$, and $\mathrm{Na}$ mass fraction (mg/kg, dry mass basis) in thyroid adenoma and thyroiditis

\begin{tabular}{|l|c|c|c|c|c|}
\hline \multirow{2}{*}{ Element } & \multicolumn{2}{|l|}{ Thyroid tissue } & & Ratio \\
\cline { 2 - 6 } & Аденома n=19 & Thyroiditis n=14 & Student's t-test $\boldsymbol{p} \leq$ & U-test $\boldsymbol{p}$ & Аденома to Thyroiditis \\
\hline $\mathrm{Br}$ & $286 \pm 104$ & $85 \pm 13$ & 0.087 & $>0.05$ & 3.36 \\
\hline $\mathrm{Ca}$ & $1143 \pm 342$ & $694 \pm 188$ & 0.270 & $>0.05$ & 1.65 \\
\hline $\mathrm{Cl}$ & $7722 \pm 1262$ & $7160 \pm 1771$ & 0.804 & $>0.05$ & 1.08 \\
\hline $\mathrm{I}$ & $961 \pm 232$ & $662 \pm 161$ & 0.298 & $>0.05$ & 1.45 \\
\hline $\mathrm{K}$ & $5137 \pm 686$ & $7268 \pm 974$ & 0.121 & $>0.05$ & 0.71 \\
\hline $\mathrm{Mg}$ & $200 \pm 36$ & $514 \pm 95$ & $\mathbf{0 . 0 1 9}$ & $\leq \mathbf{0 . 0 1}$ & 0.39 \\
\hline $\mathrm{Mn}$ & $1.60 \pm 0.51$ & $2.33 \pm 0.70$ & 0.419 & $>0.05$ & 0.69 \\
\hline $\mathrm{Na}$ & $9072 \pm 1096$ & $8271 \pm 1332$ & 0.651 & $>0.05$ & 1.10 \\
\hline
\end{tabular}

M - Arithmetic mean, SEM - standard error of mean, statistically significant values are in bold.

Table 5 Comparison the contents of $\mathrm{Br}, \mathrm{Ca}, \mathrm{Cl}, \mathrm{I}, \mathrm{K}, \mathrm{Mg}$, $\mathrm{Mn}$, and $\mathrm{Na}$ in different pathological transformation of thyroid

\begin{tabular}{|l|c|c|c|c|c|c|}
\hline Comparison with & \multicolumn{3}{|c|}{ Normal thyroid* } & \multicolumn{2}{c|}{ Colloid Goiter } & Adenoma \\
\hline Element & Goiter & Adenoma & Thyroiditis & Adenoma & Thyroiditis & Thyroiditis \\
\hline $\mathrm{Br}$ & $\uparrow$ & $\uparrow$ & $\uparrow$ & $\uparrow$ & $\uparrow$ & $=$ \\
\hline $\mathrm{Ca}$ & $=$ & $=$ & $\downarrow$ & $=$ & $\downarrow$ & $=$ \\
\hline $\mathrm{Cl}$ & $\uparrow$ & $\uparrow$ & $=$ & $=$ & $=$ & $=$ \\
\hline $\mathrm{I}$ & $\downarrow$ & $\downarrow$ & $\downarrow$ & $=$ & $\downarrow$ & $=$ \\
\hline $\mathrm{K}$ & $=$ & $=$ & $=$ & $=$ & $=$ \\
\hline $\mathrm{Mg}$ & $\uparrow$ & $\uparrow$ & $=$ & $=$ & $=$ \\
\hline $\mathrm{Mn}$ & $=$ & $=$ & $=$ & $=$ & $=$ \\
\hline $\mathrm{Na}$ & $\uparrow$ & $\uparrow$ & \multicolumn{2}{|c|}{$=$} & $=$ & $=$ \\
\hline
\end{tabular}

\section{Conclusion}

In this work, ChE analysis was carried out in the tissue samples of TBNs using INAA-SLR. It was shown that INAA-SLR is an adequate analytical tool for the non-destructive determination of $\mathrm{Br}, \mathrm{Ca}, \mathrm{Cl}, \mathrm{I}, \mathrm{K}, \mathrm{Mg}, \mathrm{Mn}$, and $\mathrm{Na}$ content in the tissue samples of human thyroid in norm and pathology, including needle-biopsy specimens. It was observed that in CG, TA and T tissues content of Br was significantly higher, while level of I was lower than in normal thyroid tissue. I accumulation in T tissue was lower than in normal thyroid and CG. In our opinion, the abnormal increase in Br level and decrease in I level in all TBNs might demonstrate an involvement of these ChE in etiology and pathogenesis of TBNs. It was suosed those great losses of I in thyroid with T, in contract to little reduced levels of I content in thyroid with CG and TA, could possibly be explored for differencial diagnosis of T. 


\section{Compliance with ethical standards}

\section{Acknowledgments}

The author is extremely grateful to Profs. B.M. Vtyurin and V.S. Medvedev, Medical Radiological Research Center, Obninsk, as well as to Dr. Yu. Choporov, Head of the Forensic Medicine Department of City Hospital, Obninsk, for sulying thyroid samples.

\section{Disclosure of conflict of interest}

The author declares that he has no competing interests.

\section{Statement of ethical approval}

All studies were approved by the Ethical Committees of the Medical Radiological Research Centre (MRRC), Obninsk. All the procedures performed in studies involving human participants were in accordance with the ethical standards of the institutional and/or national research committee and with the 1964 Helsinki declaration and its later amendments, or with comparable ethical standards.

\section{Statement of informed consent}

Informed consent was obtained from all individual participants included in the study.

\section{References}

[1] Ghartimagar D, Ghosh A, Shrestha MK, Thapa S, Talwar O Histopathological Spectrum of Non-Neoplastic and Neoplastic Lesions of Thyroid: A Descriptive Cross-sectional Study. J Nepal Med Assoc. 2020; 58(231): 856-61.

[2] Hoang VT, Trinh CT. A Review of the Pathology, Diagnosis and Management of Colloid Goitre. Eur Endocrinol. 2020; 16(2): 131-5.

[3] Popoveniuc G, Jonklaas J. Thyroid nodules. Med Clin North Am. 2012; 96(2): 329-49.

[4] Derwahl M, Studer H. Multinodular goitre: 'much more to it than simply iodine deficiency'. Baillieres Best Pract Res Clin Endocrinol Metab. 2000; 14(4): 577-600.

[5] Zaichick V. Iodine excess and thyroid cancer. J Trace Elem ExMed. 1998; 11(4): 508-9.

[6] Zaichick V, Iljina T. Dietary iodine sulementation effect on the rat thyroid ${ }^{131}$ I blastomogenic action. In: Die Bedentung der Mengen- und Spurenelemente. 18. Arbeitstangung. Jena: Friedrich-Schiller-Universitat. 1998. 294-306.

[7] Kim S, Kwon YS, Kim JY, Hong KH, Park YK. Association between iodine nutrition status and thyroid diseaserelated hormone in Korean adults: Korean National Health and Nutrition Examination Survey VI (2013-2015). Nutrients. 2019; 11(11): 2757.

[8] Vargas-Uricoechea P, Pinzón-Fernández MV, Bastidas-Sánchez BE, Jojoa-Tobar E, Ramírez-Bejarano LE, MurilloPalacios J. Iodine status in the colombian population and the impact of universal salt iodization: a double-edged sword? J Nutr Metab. 2019; 6239243.

[9] Stojsavljević A, Rovčanin B, Krstić D, Borković-Mitić S, Paunović I, Diklić A, Gavrović-Jankulović M, Manojlović D. Risk assessment of toxic and essential trace metals on the thyroid health at the tissue level: The significance of lead and selenium for colloid goiter disease. Expo Health. 2019.

[10] Fahim YA, Sharaf NE, Hasani IW, Ragab EA, Abdelhakim HK. Assessment of thyroid function and oxidative stress state in foundry workers exposed to lead. J Health Pollut. 2020; 10(27): 200903.

[11] Liu M, Song J, Jiang Y, Lin Y, Peng J, Liang H, Wang C, Jiang J, Liu X, Wei W, Peng J, Liu S, Li Y, Xu N, Zhou D, Zhang Q, Zhang J. A case-control study on the association of mineral elements exposure and thyroid tumor and goiter. Ecotoxicol Environ Saf. 2021; 208: 111615.

[12] Zaichick V. Medical elementology as a new scientific discipline. J Radioanal Nucl Chem. 2006; 269: 303-9. 
[13] Moncayo R, Moncayo H. A post-publication analysis of the idealized uer reference value of $2.5 \mathrm{mIU} / \mathrm{L}$ for TSH: Time to suort the thyroid axis with magnesium and iron especially in the setting of reproduction medicine. BBA Clin. 2017; 7: 115-9.

[14] Beyersmann D, Hartwig A. Carcinogenic metal compounds: recent insight into molecular and cellular mechanisms. Arch Toxicol. 2008; 82(8): 493-512.

[15] Martinez-Zamudio R, Ha HC. Environmental epigenetics in metal exposure. Epigenetics. 2011; 6(7): 820-7.

[16] Zaĭchik VE, Raibukhin YuS, Melnik AD, Cherkashin VI. Neutron-activation analysis in the study of the behavior of iodine in the organism. Med Radiol (Mosk). 1970; 15(1): 33-6.

[17] Ză̌chik VE, Matveenko EG, Vtiurin BM, Medvedev VS. Intrathyroid iodine in the diagnosis of thyroid cancer. Vopr Onkol. 1982; 28(3): 18-24.

[18] Zaichick V, Tsyb AF, Vtyurin BM. Trace elements and thyroid cancer. Analyst. 1995; 120(3): 817-21.

[19] Zaichick VYe, Choporov YuYa. Determination of the natural level of human intra-thyroid iodine by instrumental neutron activation analysis. J Radioanal Nucl Chem. 1996; 207(1): 153-61.

[20] Zaichick V. In vivo and in vitro alication of energy-dispersive XRF in clinical investigations: experience and the future. J Trace Elem ExMed. 1998; 11(4): 509-10.

[21] Zaichick V, Zaichick S. Energy-dispersive X-ray fluorescence of iodine in thyroid puncture biopsy specimens. J Trace Microprobe Tech. 1999; 17(2): 219-32.

[22] Zaichick V. Relevance of, and potentiality for in vivo intrathyroidal iodine determination. Ann N Y Acad Sci. 2000; 904: 630-2.

[23] Zaichick V, Zaichick S. Normal human intrathyroidal iodine. Sci Total Environ. 1997; 206(1): 39-56.

[24] Zaichick V. Human intrathyroidal iodine in health and non-thyroidal disease. In: New aspects of trace element research (Eds: M.Abdulla, M.Bost, S.Gamon, Arnaud, G.Chazot). Smith-Gordon, London, and Nishimura,Tokyo. 1999, 114-9.

[25] Zaichick V, Zaichick S. Age-related changes of some trace element contents in intact thyroid of females investigated by energy dispersive X-ray fluorescent analysis. Trends Geriatr Healthc. 2017: 1(1): 31-8.

[26] Zaichick V, Zaichick S. Age-related changes of some trace element contents in intact thyroid; f males investigated by energy dispersive X-ray fluorescent analysis. MOJ Gerontol Ger. 2017; 1(5): 00028.

[27] Zaichick V, Zaichick S. Age-related changes of $\mathrm{Br}, \mathrm{Ca}, \mathrm{Cl}, \mathrm{I}, \mathrm{K}, \mathrm{Mg}$, $\mathrm{Mn}$, and $\mathrm{Na}$ contents in intact thyroid of females investigated by neutron activation analysis. Curr Updates Aging. 2017; 1: 5.1.

[28] Zaichick V, Zaichick S. Age-related changes of $\mathrm{Br}, \mathrm{Ca}, \mathrm{Cl}, \mathrm{I}, \mathrm{K}, \mathrm{Mg}, \mathrm{Mn}$, and $\mathrm{Na}$ contents in intact thyroid of males investigated by neutron activation analysis. J Aging Age Relat Dis. 2017; 1(1): 1002.

[29] Zaichick V, Zaichick S. Age-related changes of Ag, Co, Cr, Fe, Hg, Rb, Sb, Sc, Se, and Zn contents in intact thyroid of females investigated by neutron activation analysis. J Gerontol Geriatr Med 2017; 3: 015.

[30] Zaichick V, Zaichick S. Age-related changes of Ag, Co, Cr, Fe, Hg, Rb, Sb, Sc, Se, and Zn contents in intact thyroid of males investigated by neutron activation analysis. Curr Trends Biomedical Eng Biosci. 2017; 4(4): 555644.

[31] Zaichick V, Zaichick S. Effect of age on chemical element contents in female thyroid investigated by some nuclear analytical methods. MicroMedicine. 2018; 6(1): 47-61.

[32] Zaichick V, Zaichick S. Neutron activation and X-ray fluorescent analysis in study of association between age and chemical element contents in thyroid of males. OAcc J Bio Eng Bio Sci. 2018; 2(4): 202-12.

[33] Zaichick V, Zaichick S. Variation with age of chemical element contents in females' thyroids investigated by neutron activation analysis and inductively coupled plasma atomic emission spectrometry. J Biochem Analyt Stud. 2018; 3(1): 1-10.

[34] Zaichick V, Zaichick S. Association between age and twenty chemical element contents in intact thyroid of males. SM Gerontol Geriatr Res. 2018; 2(1): 1014.

[35] Zaichick V, Zaichick S. Associations between age and 50 trace element contents and relationships in intact thyroid of males. Aging Clin ExRes. 2018; 30(9): 1059-70. 
[36] Zaichick V, Zaichick S. Possible role of inadequate quantities of intra-thyroidal bromine, rubidium and zinc in the etiology of female subclinical hypothyroidism. EC Gynaecology. 2018; 7(3): 107-15.

[37] Zaichick V, Zaichick S. Possible role of inadequate quantities of intra-thyroidal bromine, calcium and magnesium in the etiology of female subclinical hypothyroidism. Int Gyn and Women's Health. 2018; 1(3).

[38] Zaichick V, Zaichick S. Possible role of inadequate quantities of intra-thyroidal cobalt, rubidium and zinc in the etiology of female subclinical hypothyroidism. Womens Health Sci J. 2018; 2(1): 000108.

[39] Zaichick V, Zaichick S. Association between female subclinical hypothyroidism and inadequate quantities of some intra-thyroidal chemical elements investigated by X-ray fluorescence and neutron activation analysis. Gynaecology and Perinatology. 2018; 2(4): 340-55.

[40] Zaichick V, Zaichick S. Investigation of association between the high risk of female subclinical hypothyroidism and inadequate quantities of twenty intra-thyroidal chemical elements. Clin Res: Gynecol Obstet. 2018; 1(1): 118.

[41] Zaichick V, Zaichick S. Investigation of association between the high risk of female subclinical hypothyroidism and inadequate quantities of intra-thyroidal trace elements using neutron activation and inductively coupled plasma mass spectrometry. Acta Scientific Medical Sciences. 2018; 2(9): 23-37.

[42] Zaichick V. Comparison between Bromine, Calcium, Chlorine, Iodine, Potassium, Magnesium, Manganese, and Sodium Contents in Macro and Micro Follicular Colloid Goiter. Innovare Journal of Medical Sciences. 2021; 9(6): 5-9.

[43] Zaichick V. Determination of twenty chemical element contents in normal and goitrous thyroid using X-ray fluorescent and neutron activation analysis. World Journal of Advanced Research and Reviews. 2021; 11(02): 130-46

[44] Zaichick V. Evaluation of bromine, calcium, chlorine, iodine, potassium, magnesium, manganese, and sodium content in the thyroid adenomas using neutron activation analysis. Journal of Carcinogenesis \& Mutagenesis. $2021 ; 12(366): 1-8$.

[45] Zaichick V. Comparison between Bromine, Calcium, Chlorine, Iodine, Potassium, Magnesium, Manganese, and Sodium Contents in Normal Thyroid and Thyroid with Hashimoto's thyroiditis. J Clin Res Oncol. 2021; 4(1): 1-7.

[46] Zaichick V. Comparison between Bromine, Calcium, Chlorine, Iodine, Potassium, Magnesium, Manganese, and Sodium Contents in Normal Thyroid and Riedel's Struma. Journal of Biotechnology \& Bioinformatics Research. $2021 ; 3(4): 1-6$.

[47] Zaichick V, Zaichick S. Instrumental effect on the contamination of biomedical samples in the course of sampling. The Journal of Analytical Chemistry. 1996; 51(12): 1200-1205.

[48] Zaichick V, Zaichick S. A search for losses of chemical elements during freeze-drying of biological materials. J Radioanal Nucl Chem. 1997; 218(2): 249-53.

[49] Zaichick V. Alications of synthetic reference materials in the medical Radiological Research Centre. Fresenius J Anal Chem. 1995; 352: 219-23.

[50] Zaichick S, Zaichick V. The effect of age and gender on 37 chemical element contents in scalhair of healthy humans. Biol Trace Elem Res. 2010; 134(1): 41-54.

[51] Zaichick S, Zaichick V. INAA alication in the age dynamics assessment of $\mathrm{Br}, \mathrm{Ca}, \mathrm{Cl}, \mathrm{K}, \mathrm{Mg}$, $\mathrm{Mn}$, and $\mathrm{Na}$ content in the normal human prostate. J Radioanal Nucl Chem. 2011; 288(1): 197-202.

[52] Zaichick V, Zaichick S. The effect of age on $\mathrm{Br}, \mathrm{Ca}, \mathrm{Cl}, \mathrm{K}, \mathrm{Mg}, \mathrm{Mn}$, and $\mathrm{Na}$ mass fraction in pediatric and young adult prostate glands investigated by neutron activation analysis. Al Radiat Isot. 2013; 82: 145-51.

[53] Korelo AM, Zaichick V. Software to optimize the multielement INAA of medical and environmental samples. In: Activation Analysis in Environment Protection. Dubna, Russia: Joint Institute for Nuclear Research. 1993. 32632.

[54] Pavelka S. Radiometric determination of thyrotoxic effects of some xenobiotics. Rad Alic. 2016; 1(2): 155-8.

[55] Dean DS, Gharib H. Epidemiology of thyroid nodules. Best Pract Res Clin Endocrinol Metab. 2008; 22(6): $901-11$.

[56] Ihnatowicz P, Drywień M, Wątor P, Wojsiat J. The importance of nutritional factors and dietary management of Hashimoto's thyroiditis. Ann Agric Environ Med. 2020; 27(2): 184-193. 
[57] Kant R, Davis A, Verma V. Thyroid nodules: Advances in evaluation and management. Am Fam Physician. 2020; 102(5): 298-304.

[58] Leko MB, Gunjača I, Pleić N, Zemunik T. Environmental Factors Affecting Thyroid-Stimulating Hormone and Thyroid Hormone Levels. Int J Mol Sci. 2021; 22(12): 6521.

[59] Maschkovsky MD. The sedatives. In: The Medicaments, $15^{\text {th }}$ Ed. Moscow: Novaya Volna; 2005. 72-86.

[60] Schwartz GG, Klug MG. Thyroid Cancer Incidence Rates in North Dakota are Associated with Land and Water Use. Int J Environ Res Public Health. 2019; 16(20): 3805.

[61] National Toxicology Program. Toxicology and carcinogenesis studies of sodium chlorate (Cas No. 7775-09-9) in F344/N rates and B6C3F1 mice (drinking water studies). Natl Toxicol Program Tech ReSer. 2005; 517: 1-255.

[62] Parazzini F, Esposito G, Tozzi L, Tozzi S. Epidemiology of endometriosis and its comorbidities. Eur J Obstet Gynecol Reprod Biol. 2017; 209: 3-7.

[63] Sokal A, Jarmakiewicz-Czaja S, Tabarkiewicz J, FiliR. Dietary Intake of Endocrine Disrupting Substances Presents in Environment and Their Impact on Thyroid Function. Nurients. 2021; 13(3): 867.

[64] Zaichick V.X-ray fluorescence analysis of bromine for the estimation of extracellular water. J Al Radiat Isot. 1998; 49(12): 1165-9 